\title{
JURISDICTION OVER THE PETROLEUM RESOURCES OF THE CANADIAN CONTINENTAL SHELF: THE EMERGING PICTURE IAN TOWNSEND GAULT*
}

\begin{abstract}
This paper assesses the effects of the Supreme Court of Canada's judgment in the Hibernia Reference on oil and gas activities on the Newfoundland shelf and orher parts of the Canadian offshore. It also reviews other Canadian decisions respecting the offshore as well as legislative developments with respect to Canada's of fshore.

On February 11. 1985, while this paper was in its final stages of publication. Prime Minister Mulroney and Premier Peckford signed the Atlantic Accord. To acknowledge this event, the author has added an Addendum to this paper, summarizing his initial impressions on the significance of the Accord in light of the Hibernia Reference. The Addendum was prepared one week after the Atlantic Accord was signed.
\end{abstract}

\section{INTRODUCTION}

Canada has been engaged in offshore petroleum exploration for several decades. Government and industry enthusiasm for of fshore exploration has waxed and waned, but at the time of writing (late 1984) of fshore exploration is taking place on an unprecedented scale. While the results have not been as good as had been hoped, it now appears likely that by the end of the decade some of fshore petroleum fields will be in commercial production.

Although there are doubts as to the commercial viability of of fshore hydrocarbon production from some offshore areas, the corresponding constitutional uncertainties surrounding of fshore activities are now being resolved. Canada, like all coastal states, enjoys sovereign rights over the continental shelf for the purposes of the exploration for and exploitation of submarine mineral resources.' And, as in some other federal states, these rights have been in dispute between central and provincial or state governments. ${ }^{2}$ Although all coastal provinces presently maintain claims to offshore mineral jurisdiction, ${ }^{3}$ three in particular have been in the

- Associate Professor of Law, Dalhousie University, Halifax. Nova Scotia.

1. The evolution of the doctrine of the continental shelf as a rule of international law will be discussed below. The nature of the coastal state's rights over the mineral resources of the seabed adjacent to its coast are set out in Article 2(1) of the Convention on the Continental Shelf, 29th April, 1958, U.N. Doc. A/CONF. 13/L. 55; Canada-Treaty Series 1970. No. 4.

2. Offshore mineral jurisdiction was the subject of a number of cases decided by the Supreme Court of the United States in 1947 and 1950, and again in 1975. The U.S. Supreme Court found against the states concerned on each occasion, and the early cases prepared their way for a settlement legislated by Congress. Accordingly, federal $v$. state jurisdiction in the United States is no longer at issue. Some of the questions came before the Australian courts in the 1970's, and again resulted in a finding in favour of the federal government. The Australian jurisdictional question has been settled by agreements between the states and the federal government.

3. The governments of Ontario and Manitoba maintain claims to mineral jurisdiction in Hud. son Bay. British Columbia and Newfoundland, despite adverse decisions by the Courts. have not recognized federal jurisdiction: similarly, the government of Nova Scotia maintains a similar claim notwithstanding its joint management and revenue-sharing agreement with Ottawa which does not require either party to surrender jurisdiction. Quebec and Neu Brunswick continue to maintain claims to of fshore jurisdiction, and Prince Edward Island has pursued a comprehensive offshore licensing policy pursuant to its own legislation. The Territorial government of the Northwest Territories, although not maintaining an explicit claim to offshore minerals jurisdiction, has nonetheless claimed the right to levy taxes on of fshore facilities. 
vanguard of the dispute: British Columbia, Newfoundland and Nova Scotia. Protracted negotiations for a political settlement have been only partially successful. Neither British Columbia nor Newfoundland could come to an accommodation with Ottawa, and resort to the courts has, in general, been favourable to the federal position. The Supreme Court has now ruled that neither British Columbia ${ }^{4}$ nor Newfoundland ${ }^{5}$ exercise jurisdiction over the continental shelf; British Columbia does not exercise ownership of the territorial sea of Canada adjacent to its coast, ${ }^{6}$ but does own the sea, seabed and subsoil of the waters between Vancouver Island and the mainland.' These are decisions of the Supreme Court of Canada, and can only be overturned by way of constitutional amendment. Newfoundland has judicial authority (although not that of the Supreme Court of Canada) for claiming ownership of marine areas up to three nautical miles from its coast; areas seaward of that limit (the remainder of the territorial sea and the seabed of the continental shelf) are subject to federal jurisdiction. ${ }^{3}$ Nova Scotia chose a different approach. The Province was anxious to avoid delaying the start of of fshore operations and also to secure federal funding to develop its gas-prone shelf. It concluded a joint management and revenue-sharing agreement with Ottawa in March, 1982.9 The agreement ignores the jurisdictional question and, indeed, is intended to survive a judicial determination of that issue one way or the other.

The opinion of the Supreme Court in the Hibernia Reference has been long awaited. The Newfoundland-Ottawa dispute had been in progress since the 1960's, and in recent years had become increasingly, and somewhat embarrassingly, strident. Personality conflicts between the principal political participants seemed almost to ensure that no settlement could be reached, a consideration which does little credit to either side.

Premier Peckford's declared intention, following the Hibernia Reference, to seek a constitutional amendment to.invest the Province with offshore petroleum jurisdiction was unlikely to arouse much enthusiasm in the boardrooms of the companies on which he, and Canada, would be relying to produce the resources which have been the subject of this dispute. The Government of Newfoundland had not looked with much favour on the Canada-Nova Scotia agreement, but Prime Minister Mulroney, in the course of the 1984 federal election campaign, promised to implement a joint management and revenue-sharing scheme more to Newfoundland's taste if the Conservative Party won the September election. Premier Peckford promptly accepted the of fer.

4. Reference Re Offshore Mineral Rights of British Columbia (1967) S.C.R. 792 (hereinafter, the B.C. Offshore Reference).

S. Reference Re The Seabed and Subsoil of the Continental Shelf Offshore Newfoundland [1984] S D.L.R. (4th) 385 (hereinafter, the Hibernia Reference).

6. Supra n. 4.

7. A.G. Canada v. A.G. British Columbia [1984] 4 W.W.R. 289 (hereinafter, the Georgia Strait Reference); affg. (1976) I B.C.L.R. 98.

8. Reference Re Mineral and Other Natural Resources of the Continental Shelf (1983) 145 D.L.R. (3rd) 9 (hereinafter, the Newfoundland Reference).

9. Canada-Nova Scotia Agreement on Offshore Management and Revenue Sharing, March. 1982. See Doucet, "Canada-Nova Scotia Offshore Agreement: One Year Later". X.XII Alta. L. Rev. 132. 
The proposed arrangement will not invest the coastal provinces with jurisdiction. The judicial determination of rights as pertain the federal government and the governments of Newfoundland and British Columbia, described above, will stand. ${ }^{10}$ It remains to be seen how the right to legislate with respect to offshore petroleum operations (a phrase which means more than the mere implementation of a licensing system) will be divided between the two levels of government. Until the details of a joint management scheme are fully worked out, however, the Government of Canada is entitled to exercise rights over, and assume legislative responsibility for, the petroleum resources of the Newfoundland continental shelf.

The jurisdictional dispute has not been the only area of uncertainty in the offshore. Questions as to the extent of Canada's continental shelf remain. The legal regime applicable to of fshore operations generally is still bedevilled by uncertainties in some important areas. The Hibernia Reference has, however, provided some definitive answers to the question of the nature of continental shelf rights, which is of concern both to the governments concerned and to their licensees.

Much of this paper is devoted to the opinion of the Supreme Court of Canada in the Hibernia Reference. That discussion will be preceded by a brief survey of offshore jurisdiction and the history of the federalprovincial offshore jurisdictional dispute in Canada. The main discussion will be followed by a brief survey of some unresolved jurisdictional problems.

\section{THE VARIOUS FORMS OF OFFSHORE JURISDICTION}

The nature of the jurisdiction exercisable by a state over a particular marine area adjacent to it depends on the juridical category, established by international law, into which that area falls. For the present purposes, four categories may be identified: inland waters, internal waters, territorial sea and the continental shelf.

Each state exercises full sovereignty over its inland waters (lakes, rivers, etc.) and its internal waters." Inland waters include lakes and rivers. Internal waters are those sea areas which would be part of the territorial waters of a state, but for the fact they they have been enclosed by straight baselines drawn, for example, across the mouth of an estuary or a bay, to facilitate the measurement of such other of fshore zones as the territorial sea. ${ }^{12}$ The waters landward of the baselines are internal waters and the waters immediately seaward of the baselines are part of the territorial sea. Designating the boundary between inland and internal waters in a river estuary, for example, is a matter for each state to determine according to domestic legal principles. However, few states have systematically applied themselves to this task, and the courts are often

10. Supran. 4 and n. 5.

11. The United Nations Convention on the Law of the Sea, Article 8. Inland waters and internal waters are regarded as an integral part of a state.

12. The Convention on the Territorial Sea (1958) laid out some basic rules concerning the drawing of baselines, but these rules are out of date; the present state of the law is more accurately affected in Articles 7 to 14 of the Law of the Sea Convention. 
called upon to determine the status of a particular marine area (for the purposes of jurisdiction, for example). Unfortunately, such decisions tend to be ad hoc, which may, in turn, reflect the quality of submissions made by counsel. Writing for the majority of the Supreme Court in the Georgia Straits Reference, ${ }^{13}$ Dickson J., as he then was, preferred not to distinguish between internal and inland waters, on the grounds that previous Canadian court decisions had used the terms interchangeably.

For most states, the territorial sea extends twelve nautical miles either from the low-water mark or from other baselines, where these have been drawn around features such as estuaries, bays or islands. ${ }^{14}$ The territorial sea is under the sovereignty of the state, the only limitation thereto being the right of innocent passage exercisable by foreign merchant vessels. ${ }^{15}$

The term sovereignty has been used, thus far, to describe the rights exercisable by the coastal state over the three marine zones identified to this point. And sovereignty is, of course, the term used to describe the nature of the jurisdiction that a state exercises over its land territory. Does this mean, then, that inland waters, internal waters and the territorial sea are a "part" of a state? This is a question for domestic, not international, law. International law recognizes the right of each state to extend its laws to the edge of the territorial sea, provided that nothing is done to prejudice the right of innocent passage (and beyond, for certain purposes such as petroleum operations and shipping). Some Canadian law does extend to the edge of the territorial sea (e.g. the Criminal Code). ${ }^{16}$ However, the Criminal Code extends to the edge of the territorial sea by virtue of one of its sections; it does not so extend beyond the low water mark, nor would the courts have jurisdiction beyond this point unless both are extended by statute.

This rule is derived from the English case of $R$. v. Keyn (1867), 17 where the German master of a German merchant vessel was acquitted on charges of manslaughter arising out of a collision in English territorial waters between his vessel and an English merchant vessel, as a result of which one of the passengers on the latter was lost. The Court held that the realm ended at the low-water mark. Parliament had not at this time extended the jurisdiction of the English criminal law to foreign vessels within territorial waters, and the case was decided accordingly. Parliament subsequently rectified the omission by statute. ${ }^{18}$ The rule laid down in the Keyn case was specifically approved by the Supreme Court of Canada in the B.C. Offshore Reference. ${ }^{19}$ Accordingly, the law of Canada does not extend beyond the low-water mark (i.e. into internal waters, the territorial sea or, indeed, the waters superjacent to the continental shelf) in the absence of specific statutory authority. The courts

13. Supren. 7.

14. Supran. 11 at Articles 7 to 12, inclusive.

15. Id. at Articles 17 to 26, inclusive.

16. R.S.C. 1970, c. C-34, as am., s. 433.

17. (1876-77) 2 Ex. D. 63.

18. Territorial Waters Jurisdiction Act 1878 ( 41 \& 42 Vic. c. 73$)$.

19. This is perhaps unfortunate, because the decision has been much criticized on a number of grounds, and was, in any case, decided by the slender majority of 7-6. The case is fully discussed in Geoffrey Marston. The Marginal Sea (1980) Oxford University Press. 
have, however, held that criminal law extends to persons in marine areas which are inter fauces terrae, that is, between the jaws of the land. The Supreme Court of Canada in the Georgia Strait Reference clearly thought that the waters of the Straits were inter fauces terrae, and decided the case accordingly. Some of the implications of this principle are discussed below.

The fourth marine jurisdictional zone is the continental shelf and the waters superjacent thereto. The proprietary right of the Crown in right of Canada or a province does not extend beyond the limits of the territorial sea, which are the limits of Canada's sovereignty..$^{20}$ Beyond this point, international law recognizes the exercise of sovereign rights over the continental shelf, but only for the purposes of exploration for and exploitation of the mineral resources of the seabed and subsoil. ${ }^{21}$ International law does not recognize rights of ownership other than of the shelf itself, nor of its resources in their natural state. It is also important to note that neither Canada nor any province makes any claim to such ownership, and the term, therefore, is a complete misnomer vis-à-vis continental shelf petroleum resources. The preferred term is "jurisdiction". The importance of this point was stressed by the Supreme Court of Canada in the Hibernia Reference and is discussed below.

Any discussion of jurisdiction over marine petroleum resources, and the right to legislate in respect thereto, must take place against the background of the settled law with respect to of fshore jurisdiction as it has been resolved by the international community and in Canada.

\section{II. THE JURISDICTIONAL DISPUTE PRIOR TO THE HIBERNIA REFERENCE}

Canada's rights over her territorial sea and continental shelf do not depend on express or implied claims or proclamations. ${ }^{22}$ Indeed, no government in Canada has claimed rights over of fshore mineral resources (nor the territorial sea) by way of an Act of Parliament or of a Legislature. This is not to say that no claims have been made by governments in Canada with respect to those resources; they have, but only in the context of a dispute between the federal government and the various coastal provinces as to whether these rights vest in the Crown in right of Canada, or the Crown in right of the adjacent Province.

The dispute between the federal and various provincial governments concerning jurisdiction over the mineral resources of the Canadian continental shelf south of $60^{\circ}$ has been waged, with varying degrees of intensity, for some two and a half decades. Those twenty-five years have seen numerous political initiatives, a joint management arrangement, many hours of negotiations and constitutional References. The net result is a

20. The rights of cosstal states in the territorial sea have long been settled: supra n. 12. Article 1: supra n. 11, Article 2.

21. Convention on the Continental Shelf, Article 2 and supra n. 11. Article 77.

22. The significance (or lack thereon of a failure to make a declaration of rights in respect of continental shelf resources will be discussed below, but it is clear that international law does not require any such declaration to be made: id. 
joint management and revenue-sharing agreement with Nova Scotia, and defeat in the courts for both British Columbia and Newfoundland. At the time of writing, a comprehensive political settlement is once again in sight.

A full survey of the dispute would require a somewhat lengthy article. For present purposes, a brief overview of its salient features must suffice.

\section{A. 1943 TO 1977}

It is often thought that Canada is a newcomer to offshore petroleum operations. This is not so; the first well in the Canadian offshore (though not the continental shelf) was drilled from an artificial island in Hillsborough Bay, Prince Edward Island, in 1943. British Columbia was issuing of fshore petroleum permits as early as 1949. Federal licensing did not commence until 1960, two years after the Convention on the Continental Shelf was signed and a decade before this country chose to ratify that agreement.

The first clash came in 1960. In that year, the federal government issued regulations ${ }^{23}$ to govern offshore petroleum operations, holding that provincial permits (e.g. those issued by British Columbia) were ultra vires the Province. Holders of those permits were required to apply for federal licences. The two governments entered into negotiations, but these became deadlocked, partly because of personality clashes between Premier Bennett and Prime Ministers Diefenbaker and Pearson. Two decades later, a similar fate was to befall negotiations between Premier Peckford and Prime Minister Trudeau. In 1965, the federal government sought a way out of the impasse by referring the question of jurisdiction of fshore of B.C. to the Supreme Court of Canada.24 The questions referred to the Court were:

1. In respect of the lands, including the mineral and other natural resources, of the seabed and subsoil seaward from the ordinary low-water mark on the coast of the mainland and the several islands of British Columbia, outside the harbours, bays. estuaries and other similar inland waters, to the outer limit of the territorial sea of Canada, as defined in Chapter 22, as between Canada and British Columbia,

(a) Are the said lands the property of Canada or British Columbia?

(b) Has Canada or British Columbia the right to explore and exploit the said lands?

(c) Has Canada or British Columbia legislative jurisdiction in relation to the said lands?

2. In respect of the mineral and other natural resources of the seabed and subsoil beyond that part of the territorial sea of Canada referred to in Question 1, to a depth of $\mathbf{2 0 0}$ metres, or, beyond that limit, to where the depth of the superjacent waters admits of the exploitation of the mineral and other natural resources of the said areas, as between Canada and British Columbia,

(a) Has Canada or British Columbia the right to explore and exploit the said mineral and other natural resources?

(b) Has Canada or British Columbia legislative jurisdiction in relation to the said mineral and other natural resources?

Two years later, the Court handed down its unanimous answers in favour of Canada. The Government of British Columbia has never accepted this as the final determination of the issue.

23. Canada Oil \& Gas Regulations, now C.R.C. 1978, c. 1518.

24. Supran. 4. 
Meanwhile, the federal government was also doing battle on the east coast of the country. In 1964, the four Atlantic provinces submitted their claim to offshore mineral jurisdiction to a federal-provincial conference. The claim also set out the maritime boundaries of the four provinces, thus delimiting the areas within which mineral jurisdiction was claimed.

The federal government took the position that continental shelf rights and sovereignty over the territorial sea vested in the Crown in right of Canada. The coastal provinces did not, and could not, exercise extraterritorial jurisdiction of this nature. None of the provinces had entered the Canadian Confederation possessed of such rights, and neither international law nor Canadian constitutional law had invested them with such rights subsequently. The federal government was, however, willing to consider joint management and revenue-sharing proposals with the coastal provinces.

Following the decision in the 1976 B.C. Offshore Reference, the federal government took the view that the reasoning of the Supreme Court was applicable to the east coast of Canada also. ${ }^{25}$ This initial activity was followed by a period of calm (oil industry interest in the Canadian continental shelf has ebbed and flowed over the last three decades). However, in 1976, the Court of Appeal of British Columbia decided in the Georgia Strait Reference that the Province owned the sea, seabed and subsoil of the Strait, which lies between Vancouver Island and the mainland of the province. The Court held that the Supreme Court of Canada in the B.C. Offshore Reference had dealt with rights over the territorial sea and jurisdiction over petroleum operations on the continental shelf adjacent to the Province, but not marine areas such as the Strait of Georgia, which is landward of the baselines from which Canada's territorial sea in the Pacific is measured. In other words, the 1967 Reference did not, in the opinion of the Court of Appeal, deal with internal waters or inland waters. The federal government announced its intention to appeal this opinion to the Supreme Court of Canada; in the event, that appeal was not heard until 1983.

In 1972, the federal government declared a moratorium on development of fshore British Columbia on environmental grounds. The Georgia Strait Reference notwithstanding, the focus of the jurisdictional dispute now moved to the east coast. Newfoundland decided to hold out for absolute control over continental shelf resources, for reasons which will be outlined below. In contrast, the Maritime provinces began to negotiate a joint management and revenue-sharing arrangement with Ottawa.

25. Statement by Prime Minister Pearson, House of Commons Debates, (1967) vol. IV at 3969; see also: statement by Prime Minister Trudeau, House of Commons Debates, (1968) vol. III at 3342. 
[VOL. XXIII, NO. 1

\section{B. 1977 TO 1983}

In 1977, Canada and the three Maritime provinces entered into a Memorandum of Understanding concerning joint management and revenue-sharing over the continental shelf adjacent to those provinces. ${ }^{26}$ The Memorandum of Understanding was to lead to a more comprehensive agreement, but this was never concluded. The arrangement fell apart when Premier Buchanan's Conservative government came to power in Nova Scotia and withdrew its support. ${ }^{27}$ In 1980, the Legislature of that province promulgated its own offshore mineral statute, which has not been proclaimed. ${ }^{28}$

Newfoundland withdrew from the negotiations for the 1977 Memorandum of Understanding at an early stage, preferring to assert its claim to absolute jurisdiction. There were a number of reasons for insisting on sole management of the resources. Newfoundland had always insisted that its constitutional position was very different from that of British Columbia, and, hence, that the 1967 B.C. Offshore Reference could be distinguished easily (Nova Scotia also sought to emphasize its unique constitutional history). Newfoundland had, in fact, made an early "claim" to the resources of the shelf, though not by way of legislation. In 1964 Premier Smallwood, in a typically symbolic gesture, ordered that a plaque be placed on the seabed at the edge of the Newfoundland shelf, as if showing the boundaries of an area appertaining to the Province. ${ }^{29}$

The Newfoundland claim to of fshore minerals is prompted not only by the desire to develop a resource base, but also by the desire to be in a position to control the pace of development, thus preventing damage to the social structure of the province. The provincial government had witnessed the impact of offshore oil in parts of eastern Scotland and the west coast of Norway. It wished to prevent the dislocation and disruption which those areas experienced and continue to experience. The only way this could be done was by exercising control on the basis of lawful jurisdiction over petroleum resources of the continental shelf.

26. See. the "Submission on Submarine Mineral Rights by the Provinces of Nova Scotia, New Brunswick, Prince Edward Island and Newfoundland to the Federal/Provincial Conference, October, 1964". The present status of the boundaries delimited in this document is a matter for some doubt, although the Canada-Nova Scotia Resources Agreement incorporated the provinces' boundaries as set out in the Submission. Prince Edward Island carries on a licensing policy with respect to offshore petroleum operations within the area allotted to it under the Agreement. However, some modification of the boundary line in the Gulf of Maine may be required following the decision of the International Court on the course of the U.S.-Canada boundary there, and following a settlement in the continental shelf boundary dispute with France with respect to St. Pierre and Miquelon, the background to which disputes is discussed briefly later in this paper.

27. On the Nova Scotia claim to exclusive of fshore resource jurisdiction. sce Foley. "Nova Scotia's Case for Coastal and Offshore Resources" (1981) 13 Ottawa L. Rev. 281.

28. The Petroleum Resources Act, S.N.S. 1980, c. 12.

29. The Newfoundland claim is set out and discussed in a number of articles. See, in particular, Martin, "Newfoundland's Case on Offshore Minerals" (1975) 7 Ottawa L. Rev. 34. See also Arvay, "Newfoundland's Claims to Offshore Mineral Resources" (1979) 5 Canadian Public Policy 32; Inions, "Newfoundland Offshore Claims" (1981) XIX Alta. L. Rev. 461; Ippolitio, "Newfoundland and the Continental Shelf" (1976) Columbia Journal of Transnational Law 138; and Swan. "The Newfoundland Offshore Claims" (1976) 22 MeGill L. J. 541 . All of the above articles antedate the Hibernia Reference by some years. 
The legal arguments are complex but may be summarized as follows. Assuming that Newfoundland was an independent state before March 31,1949 , the date of union with Canada, international law had recognized the doctrine of the continental shelf as a rule of customary international law by that date, such that all states enjoyed these rights with or without express claim or proclamation. Furthermore, nothing in the Terms of Union with Canada deprived Newfoundland of those rights, which she still possessed. Even if continental shelf rights were not part of customary international law by the date of union, those rights were subsequently declared to have had retroactive effect by the International Court of Justice. ${ }^{30}$ Therefore, they vested in Newfoundland prior to union (even though the rule of the continental shelf had not been established per se) and were still enjoyed by the Province. (Further aspects of the provincial case are discussed in the context of the Hibernia Reference, below.)

The Nova Scotia government's decision to reinstate its claim to sole jurisdiction over offshore minerals received direct encouragement from the short-lived federal Conservative government of 1979-80. Prime Minister Clark agreed to a Newfoundland proposal which would place offshore administration in the hands of coastal provinces, which would also be entitled to $100 \%$ of any revenues flowing from production. ${ }^{31}$ However, the Clark administration left office before this undertaking could be implemented, and the succeeding Liberal administration made it clear that a joint arrangement was now preferred.

The introduction of the Nova Scotia legislation prompted the then Minister of Energy, Mines and Resources to comment that recourse to the courts was the only option facing the federal government. 32 However, Nova Scotia and Ottawa conducted the negotiations which led to their agreement with something less than the publicity which was to mark discussions between Ottawa and Newfoundland.

The result of these negotiations, the Canada-Nova Scotia Agreement on Joint Management and Revenue Sharing, was signed by the Premier and the Prime Minister in March, 1982. The Agreement guarantees the Province a flow of revenue from offshore production, depending on the economic conditions prevailing in Nova Scotia. The Province has an input into decision-making but, in the last resort, cannot prevent the implementation of a federal decision. The Province agreed to accept the federal licensing system (the Canada Oil and Gas Act), the legal regime for management (the Oil and Gas Production and Conservation Act) and

30. North Sea Continental Shelf Cases, (1969) I.C.J. Rep. 3 at 22.

31. Details of the exchange between Prime Minister Clark and Premier Peckford appear in Document 830-74/002, Canadian Intergovernmental Conference Secretariat, "Exchange of Letters Made Public Re Offshore Mineral Resources".

32. In the National Energy Program, announced in October, 1980, the federal government, citing claims to "ownership" by Newfoundland and Nova Scotia, said that it was " . . anxious to refer the matter of ownership quickly to the Supreme Court. Uncertainty . . . is not conducive to the rapid development of the oil and gas potential of this promising region (i.e. the east coast of fshore)": "The National Energy Program 1980". Energy. Mines and Resources Canada at 42. 
the federal administrative system for the offshore (the Canada Oil and Gas Lands Administration or "COGLA"). The Agreement has now been implemented in federal and provincial legislation. ${ }^{33}$

The Nova Scotia government clearly preferred to see operations on the Scotian shelf develop, rather than face stagnation while a war of attrition with Ottawa was waged. The Agreement also provides for an injection of federal funds to assist in the development of the Scotian shelf; such a provision is perhaps more important for Nova Scotia's gas-prone shelf (where heavy investment is required up front) than for the Newfoundland oil-prone shelf.

By March 1982, however, the dispute with Newfoundland had taken a different course. Premier Peckford had placed a compromise proposal on the table which would have provided for equal federal and provincial representation on a management board presided over by an independent chairman. This board would make the vital pace-of-development decisions with respect to petroleum operations on the Newfoundland shelf. The federal government was willing to concede the revenues from offshore production and provincial participation in management and decision-making; it was not willing to concede ultimate control.

In early 1982, the Newfoundland government had been particularly upset by the intervention of the Attorney General of Canada in a case before the Federal Court concerning the jurisdiction of the federal, as opposed to Newfoundland, Labour Relations Board in a case concerning the certification of some unions active on the Grand Banks. The Attorney General proposed that the issue should be determined by reference to the merits of the claims made by Canada and Newfoundland to of fshore mineral jurisdiction. In the event, the Federal Court decided the issue on the grounds of the federal jurisdiction over navigation and shipping and held that the of fshore minerals dispute was irrelevant. ${ }^{34}$ But the Province interpreted the federal intervention as a sign of bad faith and an indication that final recourse to the courts was unlikely to be delayed. It may, therefore, have decided to go to court on its own terms.

On February 18, 1982, the Lieutenant Governor of Newfoundland referred the following question to the Newfoundland Court of Appeal: ${ }^{35}$

Do the lands, mines, minerals, royalties or other rights, including the right to . . . legislate, with respect to the mineral and other natural resources of the seabed and subsoil from the ordinary low-water mark of the Province of New foundland to the seaward limit of the continental shelf or any part thereof belong or otherwise appertain to the Province of Newfoundland?

33. The legislation is as follows: (a) federal: the Canada-Nova Scotia Oil and Gas Agreement Act, S.C. 1983-84, c. 43 (imptementing the Agreement); (b) provincial: the Canada-Nova Scotia Oil and Gas Agreement (Nova Scotia) Act, S.N.S. 1984, c. 2 (mirroring the federal Act cited above); the Offshore Oil and Gas Act, S.N.S. 1984, c. 8 (implementing parts of the Canada Oil and Gas Act, S.C. 1980-81-82-83, c. 81); the Oil and Gas Production and Conservation (Nova Scotia) Act, S.N.S. 1984, c. 9 (implementing the Oil and Gas Production and Conservation Act, R.S.C. 1970, c. 4). At the same time, some provincial statutes were amended to enable the Lieutenant Governor in Council to exempt parts of Nova Scotia Lands from their jurisdiction: the Petroleum Resources Act, S.N.S. 1980, c. 12 as am. S.N.S. 1984, c. 64; the Energy and Mineral Resources Conservation Act. S.N.S. 1980. c. S, 13 as am. S.N.S. 1984, c. 65; and the Gas Utilities Act, S.N.S. 1980, c. 7 as am. S.N.S. 1984, c. 61 .

34. Re Seafarer's Union and Crosbie Services Lid., (1982) I35 D.L.R. (3d) 485.

35. Supran. 8, at 12. 
From the discussion of offshore jurisdiction in Part II of this paper, it can be seen that the Court was being asked to identify the marine areas subject to Canadian jurisdiction seaward of the low-water mark, and to allocate rights available with respect thereto between the Crown in right of the Province and the Crown in right of Canada. In the event, the opinion of the Court was that the Province exercised ownership over the sea, seabed and its subsoil seaward from the low-water mark to the three nautical mile limit, corresponding to the territorial sea of the Dominion of Newfoundland at the date of Confederation. Seaward of the three nautical mile limit (i.e., the remainder of the territorial sea of Canada, from three to twelve nautical miles and the continental shelf adjacent to the Province) any rights available, such as sovereignty over the territorial sea and its seabed and sovereign rights over the shelf for the purposes of the search for and production of minerals, vested in the Crown in right of Canada.

The Newfoundland Court of Appeal, in considering the submissions made by counsel for the parties, felt itself to be bound, in the last resort, by the opinion of the Supreme Court of Canada in the B.C. Offshore Reference, 36 save only for the three nautical mile limit, a concession to the constitutional and historical position of Newfoundland before it became a province of Canada. Those constitutional and historical arguments did not persuade the Court to distinguish the 1967 B.C. Offshore Reference.

It will be noted that the question referred invoked the wording of s. 109 of the Constitution Act, ${ }^{37}$ which refers to "All Lands, Mines, Minerals, and Royalties...." In essence, the Province was asking the Court whether it enjoyed rights over of fshore minerals similar to those enjoyed by all provinces in respect of the natural resources situated therein. Newfoundland's position was that of fshore mineral rights vested in the adjacent coastal province in the same way as minerals on land. The Courts have only partially agreed with this position, but the provincial claim is partially reflected in the draft Mulroney-Peckford accord, which provides that the coastal provinces will be entitled to collect revenues from of fshore mineral production as if those operations were taking place "on land". As discussed at Part VIII, infra, their formal "Atlantic Accord" was signed on February 11, 1985.

\section{THE HIBERNIA REFERENCE}

On May 19, 1982, the Governor in Council referred the following questions to the Supreme Court of Canada: ${ }^{38}$

In respect of the mineral and other natural resources of the seabed and subsoil of the continental shelf, in the area offshore Newfoundland approximately 320 kilometres (170 nautical miles) east-south-east of St. John's, Newfoundland, bounded by $60^{\circ} 30^{\prime}$ north latitude and $70^{\circ} 00^{\prime}$ north latitude by $80^{\circ} 30^{\prime}$ west longitude and $90^{\circ}$ west longitude. where resource exploration is being conducted and more particularly delimited on the map attached hereto as the Appendix to this Order, as between Canada and Newfoundland, pursuant to The Newfoundland Act, 1949 or otherwise, has Canada or Newfoundland

36. Supran. 4.

37. Constitution Act 1867, s. 109.

38. The Order of Reference was made by P.C. 1982-1s09. 
(1) the right to explore and exploit the said mineral and other natural resources? and

(2) legislative jurisdiction to make laws in relation to the exploration and exploitation of the said mineral and other natural resources?

The Federal Attorney General argued that the answer to both questions should be "Canada"; the Attorney General of Newfoundland, supported by the Attorneys General of Nova Scotia, New Brunswick, Manitoba, British Columbia, Prince Edward Island and Alberta submitted that the questions should be answered in favour of the Province.

The questions referred by this, the third Order of Reference concerning jurisdiction over petroleum operations on the Canadian continental shelf and the fourth on of fshore jurisdiction generally, did not ask the Court to pronounce on the validity of legislation promulgated by either level of government. Accordingly, no legislation applicable to of fshore petroleum operations was discussed in the judgment. By implication, however, the Court was being asked to determine whether the federal licensing statute, the Canada Oil and Gas Act, or the Newfoundland licensing and management enactment, the Petroleum and Natural Gas Act, was intra vires Parliament or the provincial Legislature, respectively. The "right to legislate" with respect to petroleum operations on the shelf is presumably to be narrowly construed to refer to the granting of licences and control over the conduct of exploration and production. It does not necessarily refer to the broader question of the right to extend federal or provincial law generally to of fshore installations.

\section{A. THE OFFSHORE AREA COVERED BY THE HIBERNIA REFERENCE}

The Court fixed on the legal significance of confining the questions to the rectangular area leased to a consortium led by Mobil Oil Canada, Ltd., in which the Hibernia oil field was situated. That this was a part of the continental shelf alone, and, hence, that questions concerning jurisdiction over internal waters and the territorial sea of Canada adjacent to the province need not be considered. However, as the Court pointed out,

It is not suggested that the legal issues are any different in respect of Hibernia than in

respect of any other portion of the continental shelf off Newfoundland.

The decision of the Court would, therefore, apply to the whole of the shelf adjacent to the Province. It will be shown below that the extent of this area is still a matter for some conjecture. The federal Reference concerned a relatively small part of the Canadian offshore area compared to the area covered by the Newfoundland Reference. That limitation was, perhaps, dictated by the wish to avoid pre-empting the deliberations of the Newfoundland Court of Appeal. In the event, the hearings on the federal Reference did not take place until judgment in the provincial Court had been rendered. By extending the area covered by its opinion to the entire Newfoundland shelf, the Supreme Court of Canada made it possible for analysts to compare the Hibernia decision to its own decision in 1967, and to a part of the judgment of the Newfoundland Court. However, it should be noted that in none of these opinions was the geographical limit of the continental shelf commented on. Indeed, the questions posed in the Hibernia Reference and the Georgia Strait 
Reference are the only ones where there is any degree of specificity, other than by the use of terms such as "territorial sea" and "continental shelf". The former term has a meaning in Canadian law, but not the latter. Can it therefore be assumed that the phrase "continental shelf" is used in either of the questions posed, or in the Hibernia opinion itself, in its geographical, or legal, meaning? As was shown in Part II of this paper, the two meanings are quite distinct. The Newfoundland decision was not before the Supreme Court in the Hibernia Reference. However, the issues before the two Courts coincided in respect of the Newfoundland continental shelf, and because all argument in the later case addressed the reasons of the Court in the earlier with respect to the continental shelf, the Supreme Court decided it could properly comment on the judgment in the Newfoundland Reference, but only in so far as it related to jurisdiction over and the right to legislate in respect of the mineral resources of the shelf.

\section{B. THE IMPACT OF THE B.C. OFFSHORE REFERENCE}

The starting point for the judgment was the Supreme Court's earlier decision concerning offshore jurisdiction, the B.C. Offshore Reference, 1967. The Attorney General of Newfoundland suggested that Newfoundland's historical and constitutional position was so different from that of British Columbia that the 1967 judgment could be distinguished in the present case or, in the alternative, that the earlier case should be reviewed and overruled. But the 1967 judgment itself could not be relied on by the Court in the present case, since much of the argument therein had concerned sovereignty over the territorial sea of Canada adjacent to British Columbia. The Court had answered that question in favour of Canada, and from there it was a logical step to hold that if the Province had not acquired rights over the territorial sea, rights over the resources of the continental shelf were also unavailable to it. Continental shelf rights, therefore, followed territorial sea rights. But sovereignty over the territorial sea as between the federal and Newfoundland Crowns was not at issue in the Hibernia Reference. The Supreme Court was, therefore, unable to use such a discussion as a point of departure for its analysis of continental shelf rights. The Court was also obliged to consider arguments concerning the continental shelf, both as a rule of international law and in Canadian constitutional law, a task it had been able to avoid in the 1967 B.C. Offshore Reference.

However, the opinion of the Supreme Court in the 1967 B.C. Offshore Reference, insofar as it applied to the Canadian continental shelf, was implicitly presumed by the Court to apply to the Newfoundland shelf. It was, therefore, for the Province to show that its constitutional position prior to joining the Canadian federation could be successfully distinguished from that of British Columbia. To that extent, the question of federal $v$. provincial jurisdiction in the shelf was not re-thought in the Hibernia Reference.

The Court then moved to an examination of the evolution of the doctrine of the continental shelf as a rule of international law. It noted that both Canada and Newfoundland were claiming the rights of coastal states in respect of of fhore mineral resources as articulated by Article 2 
of the Convention on the Continental Shelf. Neither. had made any claim to jurisdiction over of fshore minerals before that treaty was drafted. The Court was careful to emphasize the connection between the rights claimed by the parties and those recognized by the international community: "The rights claimed [by the two parties] are those accorded by operation of international law"'.

The Court surveyed the evolution of the doctrine of the shelf as manifested by state practice and treaty. Its conclusion on the nature of the rights exercisable over continental shelf minerals was clear and unequivocal: the continental shelf was not territory and not subject to ownership in the same way as the land territory of a state. The continental shelf off the coast of Newfoundland was outside Canada. The Court went on to say: ${ }^{39}$

Much of the argument in the present case is based on the assumption that the continen-
tal shelf rights are proprietary. We do not think continental shelf rights are proprietary
in the ordinary sense. In the words of the 1958 Geneva Convention, they are "sovereign
rights" and they appertain to the coastal State as an extension of rights beyond where its
ordinary sovereignty is exercised. In pith and substance they are an extra-territorial
manifestation of, and an incident of, the external sovereignty of a coastal State.

Seldom has the essential difference between rights exercisable by a state onshore, and the rights exercisable in respect of operations in connection with of fshore minerals, been so clearly articulated.

The Court went on to consider the possibility of distinguishing the 1967 B.C. Offshore Reference in the instant case. It held that the earlier opinion could only be ignored if Newfoundland succeeded on each of the three following points:

(i) International law must have recognized the right to explore and exploit in the cootinental shelf prior to Newfoundland's entry into Confederation on March 31st, 1949;

(ii) The Crown in right of Newfoundland must have been in the position to acquire these rights:

(iii) The Crown in right of Newfoundland must not have lost those rights under the Terms of Union with Canada.

The Court addressed the constitutional arguments first, and examined the Newfoundland case assuming, for the purpose of argument, that on the date of entry into Confederation, the doctrine of the continental shelf was indeed recognized as a rule of international law. Much of the argument by counsel concerned whether or not Newfoundland had been an independent sovereign state at any point before its entry into Confederation.

Bearing in mind its earlier remarks that continental shelf rights were acquired as an incident of external sovereignty, the Court searched for evidence that Newfoundland had, before entering Confederation, exercised external sovereignty. It was held to be clear, from the constitutional and historical record, that Newfoundland had achieved internal sovereignty in 1855 and Dominion status in 1926. From 1934 until its entry into Confederation, Newfoundland was ruled by a Commission of Government, comprised of the Governor and a council of six ministers, three appointed by Westminster and three by the Dominion. The record

39. Supra n. S, at 396. 
also showed that Newfoundland did not exercise external sovereignty during that period. The Court was also inclined to doubt that between 1926 and 1934 Newfoundland exercised external sovereignty because it did not adopt the Statute of Westminster ${ }^{20}(1931)$ which made it possible for the various Dominions (Canada, Australia, New Zealand, South Africa, the Irish Free State and Newfoundland) to acquire such rights.

The Court was prepared to accept that the Commission of Government was indeed the government of Newfoundland, but the arrangement did not amount to government by Newfoundland. The Court recited a number of examples from British constitutional practice which indicated that the Crown in right of the United Kingdom exercised external sovereignty on behalf of Newfoundland, and, accordingly:

Any continental shelf rights available at international law between 1934 and 1949 therefore accrued to the Crown in right of the United Kingdom, and not to the Crown in right of Newfoundland.

\section{THE EFFECT OF THE TERMS OF UNION WITH CANADA}

The Court then considered an alternative argument of the Attorney General of Newfoundland, that even if Newfoundland had lost its external sovereignty during the period of the Commission of Government, under Term 7 of the Terms of Union with Canada, that external sovereignty revived when the Dominion entered into Confederation. Term 7 is as follows:

\section{Provincial Constitution}

7. The Constitution of Newfoundland as it existed immediately prior to the sixteenth day of February, 1934, is revived at the date of Union and shall, subject to these Terms and the British North America Acts, 1867 to 1946, continue as the Constitution of the Province of Newfoundland from and after the date of Union, until altered under the authority of the said Acts.

The Province argued that any rights in respect of the natural resources of the continental shelf arising during the Commission of Government vested in Newfoundland immediately prior to union with Canada by virtue of this provision. It was suggested that Newfoundland's preCommission of Government constitution revived the instant before it entered union, and thus, it enjoyed continental shelf rights like any other state.

The Supreme Court held that Term 7, if read in conjunction with the other Terms of Union and the British North America Act, provided instead for the internal government of Newfoundland as a province of Canada, and could not operate so as to bestow on the Province rights over the continental shelf, if such rights existed at international law on March 31, 1949.

The Attorney General of Newfoundland had a further argument based on the Terms of Union. Term 37 provides that all lands, mines, minerals and royalties belonging to Newfoundland at the date of union shall belong to the new Province. A similar provision appears in section 109 of the Constitution Act, 1867. But the Attorney General of Newfoundland

40. Statute of Westminster, (1931) $22 \& 23$ Geo. S. c.4, s. 3: "It is hereby declared and enacted that the Parliament of a Dominion has full power to make laws having extra-territorial operation." 
pointed to a difference: section 109 provides that natural resources shall belong to the provinces of Ontario, Quebec, Nova Scotia and New Brunswick "in which the same are situate or arise". This phrase does not appear in Term 37, and the Attorney General of Newfoundland argued that since Term 3 renders section 109 applicable to Newfoundland unless the contrary was stated, Term 37 would be superfluous unless it was accepted that its intention was to reserve to the Province proprietary rights within and outside the land mass, or ordinary boundaries, of the Province. The same argument had been advanced before the Court of Appeal of Newfoundland which, drawing upon the B.C. Offshore Reference of 1967, held that it was necessary for Newfoundland to show that rights to offshore minerals had been claimed by a specific constitutional act. The historical record of Newfoundland prior to union disclosed no such act.

This reference by the Newfoundland Court to the 1967 decision was partially misleading, since the earlier decision concentrated on the question of sovereignty over the territorial sea, regarding continental shelf rights as a somewhat secondary issue in the light of the initial determination in favour of the Crown in right of Canada. Thus, the Supreme Court, in the present case, did not consider it fatal that Newfoundland had not made a specific claim to continental shelf jurisdiction prior to the date of union. Indeed, as the Court pointed out, the Crown in right of Canada has not made any express claim to continental shelf jurisdiction. It should also be noted that international law does not require an express claim or proclamation in respect of continental shelf rights.

The Term 37 argument was not accepted by the Court. It considered Term 37 as being one of a group of provisions concerning the division of property between the new Province and the Crown in right of Canada. The difference between Term 37 and section 109 could be explained by the grammatical necessity, in the latter, of wording to make it clear that the property which was situated in three colonies was to be retained by four provinces. Finally, the Court pointed to the intention of Term 37 (and Term 35) of the Terms of Union between Newfoundland and Canada, their function vis-à-vis proprietary rights, and the inapplicability of such provisions to continental shelf rights, which were not, as the Court had already found, proprietary in nature. Finally, the Court concluded that had Newfoundland acquired any rights over the continental shelf before union with Canada, the Terms of Union would have allocated those rights to the Crown in right of Canada, and not the Crown in right of the Province.

\section{WAS THE DOCTRINE OF THE CONTINENTAL SHELF A RULE OF LAW IN 1949 ?}

In its examination of Newfoundland's claim to offshore jurisdiction, the Court had, to this point, assumed for the sake of argument that continental shelf rights were available to the Dominion of Newfoundland at the time it entered union with Canada. The Court now proceeded to discuss the state of international law vis-à-vis of fshore mineral resources as of March 31, 1949. Both the Supreme Court of Canada and the Court of Appeal of Newfoundland had been almost inundated by information 
from the parties on this very question. The factums of both Attorneys General disclose a painstaking discussion of the evolution of the doctrine of the continental shelf as a rule of international law, almost on a stateby-state and year-by-year basis. Several of the proclamations, declarations or enactments of states were presented, as were relevant pronouncements of the International Court of Justice and comments by leading writers on the subject.

The Court distinguished at the outset between the two sources of international law, namely, treaties and customary international law. The former did not come into play until 1958, with the signing of the Convention on the Continental Shelf. If the doctrine of the shelf became a rule of international law at the date of union, then it could only have been through the customary international law processes. ${ }^{41}$ Accordingly, the Court was obliged to survey state practice on continental shelf claims before the relevant date in order to ascertain whether the rule of law had indeed evolved by then. The survey commenced with the Gulf of Paria Treaty, concluded between the United Kingdom and Venezuela in 1942, 42 and continued with the Truman Proclamation of September, 1945, commonly taken to be the first unequivocal and unambiguous claim to jurisdiction over the shelf for the purposes of oil and gas activities. ${ }^{43}$ The Truman Proclamation was followed by declarations and enactments from seven Central and South American countries ${ }^{44}$ and annexations of the seabed adjacent to the British colonies of Jamaica and the Bahamas. ${ }^{45}$ Within a few months of Newfoundland's entry into Confederation, the United Kingdom had issued declarations on behalf of a number of its protected states in the Arabian Gulf area. The record disclosed that there had been a request from Newfoundland to the United Kingdom to make such a declaration on behalf of the Dominion, but such declaration was never made prior to union with Canada.

The Court appeared to take its cue from a number of events taking place and opinions expressed after March 31, 1949. The decision of Lord Asquith in the Abu Dhabi Arbitration (1951) ${ }^{46}$ was clearly as persuasive for the Supreme Court as it has been for many others, in suggesting that the claims made in the years immediately following the Truman Pro-

41. A rule of customary international law evolves from state practice. If a number of states make unilateral claims which are consistent and uniform as to nature and extent and in the belief that they have the right to make such claims, then, in the absence of protest from other countries, such practice evolves from a mere usage to a rule of customary international law. Article 38(1) of the Statute of the International Court of Justice directs that body to apply treaties and then international custom "as evidence of a general practice accepted as law" in the determination of matters which come before it.

42. This treaty divided the seabed and subsoil of the Gulf, which separates Trinidad from Venezuela, equally between the parties.

43. Department of State Bulletin 4327 . September 30, 1945.

44. The Truman Proclamation was closely followed by declarations (of one kind or another) from, among others, Mexico, Argentina, Chile and Peru.

45. It must be emphasized that the British government did not wish to prociaim sovereignty over marine areas beyond the limits of the territorial sea. Rather, it wished to secure title to the continental shelf, and annexation. i.e. a declaration of full sovereignty, was, at that time, the only way in which, in the opinion of the British government, title to the continental shelf could be secured.

46. Petroleum Development Lid. v. Sheikh of Abu Dhabi(19S1) I.L.R. 144. 
clamation were not sufficiently consistent in their purpose, nature and extent to justify the conclusion that a rule of international customary law had developed with respect to the continental shelf, at least not before 1951.

One further argument, put forward by the Attorney General of Newfoundland, remains to be considered. This was to the effect that even if customary international law had not recognized continental shelf rights by 1949, the International Court of Justice had, in the course of its judgment in the North Sea Continental Shelf Cases (1969), ${ }^{77}$ accorded these rights retroactive recognition. The relevant passage in that judgment is as follows: 48

... the most fundamental of all the rules of law relating to the continental shelf ... [is] that the rights of the coastal State in respect of the area of continental sheif that constitutes a natural prolongation of its land territory into and under the sea exist ipso facto and $a b$ initio, by virtue of its sovereignty over the land, and as an extension of it in an exercise of sovereign rights for the purpose of exploring the sea bed and exploiting its natural resources. In short, there is here an inherent right. In order to exercise it, no special legal process has to be gone through, nor have any special legal acts to be performed.

The interpretation of this passage has been much debated (and it should be pointed out that the decision as a whole has been heavily criticized on a number of grounds). Did the Court mean that such rights adhered to coastal states from the beginnings of geological time, or at any point up to and including the date when continental shelf rights were recognized by international law? The Supreme Court of Canada preferred the latter interpretation: 49

In our view, continental shelf rights have no retroactive application to a time before they were recognized by international law.

The Court went on to point out that, even if the retroactivity argument could be accepted, it would operate in favour of Canada, not Newfoundland.

In conclusion, therefore, the Court held that Newfoundland would not have enjoyed, prior to its entry into Confederation, any rights over the continental shelf, since such rights had not been recognized at international law by March 31, 1949. Nor could the Dominion of Newfoundland have acquired any rights, had they been available, prior to that date.

\section{E. LEGISLATIVE JURISDICTION}

The Court disposed of the question of the "right to legislate" with some dispatch. It held that since Canada enjoyed the right to conduct oil and gas operations on the continental shelf, legislative jurisdiction followed: 50

There is nothing in s. 92 of the Constitution Act, 1867 which could confer legislative jurisdiction upon Newfoundland in respect of such rights held by Canada. Legislative jurisdiction falls to Canada under the peace, order and good government power in its residual capacity.
47. Supra n. 30.
48. Id.
49. Supra n. 5 at 417.
so. Id. at 418. 
The Court pointed to the provisions of sections 92 and $92 \mathrm{~A}$ which confine provincial jurisdiction concerning property and civil rights, and legislation in respect of resource development, to the territory of the province, i.e. to areas landward of the low-water mark or marked by interprovincial boundaries.

\section{WHAT THE HIBERNIA REFERENCE DID NOT COVER}

The Hibernia Reference does not solve all the jurisdictional problems in the Newfoundland offshore. The question of jurisdiction from the low-water mark to the edge of the territorial sea remains. As matters now stand, Newfoundland exercises jurisdiction up to three nautical miles, but from three to twelve nautical miles, the Court of Appeal of Newfoundland ruled in favour of the Crown in right of Canada. Both that Court and the Supreme Court of Canada decided in favour of the federal Crown in respect of rights available on the shelf. However, the phrase "Newfoundland offshore" appears in the judgments of both Courts and is otherwise in common use. What exactly is meant by this phrase? Similarly, is it possible to state with any better degree of certainty what is meant by the "Scotian Shelf"'? What is the extent of the B.C. of fshore?

Other problems concerning the seaward extent of the continental shelf, boundaries between Canada and other countries, and boundaries between the provinces and territories of Canada will now be examined.

The question before the Court in the Hibernia Reference was severely limited as to geographical extent, but the Court extended the ambit of its ruling to the whole of the continental shelf adjacent to the Province of Newfoundland and Labrador. The Court was not asked to rule on the extent of that area, nor could it have done so with any ease. The "Newfoundland of fshore area" has not been authoritatively defined by either level of government. The problem is threefold: first, the seaward limits of of fshore jurisdiction must be faced; then there is the question of of fshore boundaries with other countries, especially those with the islands of St. Pierre and Miquelon. Thirdly, there are boundaries between the several east coast provinces and the Northwest Territories. Where do these matters stand at present?

\section{A. SEAWARD EXTENT OF THE SHELF}

The nature and extent of Canada's jurisdiction over the continental shelf for the purposes of exploration for and exploitation of submarine minerals derives from international law, specifically, from the Convention on the Continental Shelf (1958) which Canada ratified in 1970. That Convention fixed the seaward extent of the continental shelf as the 200metre isobath or beyond that limit to where the depth of superjacent waters admits of exploitation of minerals. That definition, however, was formulated at a time when even operations at the 200-metre isobath were beyond the technological capability of the oil industry. The 1958 Convention was overtaken by improvements in that technology at a rate which could not possibly have been foreseen but, in the result, the 200-metre isobath/exploitability test would permit states to extend their of fshore jurisdiction indefinitely until, theoretically, the entire seabed of the world 
would be divided between the various coastal states: Such a development would have disastrous consequences for the principle of the freedom of the seas.

It was to prevent such a development and to protect the interests of the landlocked states that the international community recognized the principle that there is a limit to coastal state jurisdiction over the of fshore. Jurisdiction for the purposes of hydrocarbon activities is fixed by the Law of the Sea Convention at either 200 nautical miles, measured from the baselines, or the outer edge of the continental margin, whichever is the greater. The Convention incorporates a complex formula for determining the edge of the continental margin, but a much simplified variant of the formula of Article 76 appears in several federal statutes, including the Canada Oil and Gas Act, the Oil and Gas Production and Conservation Act and the National Energy Board Act, for the purposes of fixing the seaward extent of the Canada Lands. ${ }^{51}$

Canadian law and international law are, therefore, moving in the same direction in this respect - towards fixing a seaward limit to the Canadian continental margin. The task remains of determining exactly where this limit lies. Each state which becomes a party to the Law of the Sea Convention will be required to fix and publish the seaward extent of its jurisdiction. Before Canada can do this, outstanding matters such as the drawing of baselines must be completed. Some government maps have appeared which purport to show the seaward extent of the continental margin, e.g. the map appended to the Canada-Nova Scotia Offshore Resources Agreement, which is expressly stated to be the result of the application of Article 76. The outline map of the Canada Lands reproduced in the National Energy Program and various COGLA publications is, with respect to the offshore areas there shown, a further example of the application of the new rule. The federal government has launched a comprehensive review of the Law of the Sea Convention, and it is expected that a decision on its ratification made will be made when this review has been completed.

\section{B. BOUNDARIES WITH OTHER STATES}

Progress of a sort is being made in the delimitation of international boundaries in the east coast of fshore. Canada and the United States submitted their longstanding dispute concerning the course of their maritime boundary in the Gulf of Maine (i.e. a line which will affix the respective jurisdiction of the two countries over hydrocarbon activities and fishing) to the International Court of Justice, which heard argument in the spring of 1984. A decision is expected in late 1984 (and, indeed, the decision was then rendered, although not in sufficient time to permit a review of it in this paper). Canada's offshore boundary with Greenland in Baffin Bay and Davis Strait was fixed by treaty in 1971,52 but the southern terminal of the boundary must be extended further into the Atlantic at a future

51. Canada Oil and Gas Act, S.C. 1980-81-82-83, c. 81, s. 2(1); National Energy Board Act, R.S.C. 1970, c. N-6, as am.: Oil and Gas Production and Conservation Act. R.S.C. 1970. c. O-1, as am.

52. Agreement on the Delimitation of the Continental Shelf between Canada and Greenland. December 17, 1973, 1973 Canada Treaty Series no. 16. 
date. The most serious of fshore boundary problem is that between Newfoundland and St. Pierre and Miquelon. France claims a 200 nautical mile zone around the islands (modified in areas opposite to the island of Newfoundland) and has accordingly issued licences to Elf Aquatain. Canada has contested the French claim and has issued overlapping permits to Gulf Resources Canada, Inc. Negotiations between the two governments have been in progress in a somewhat sporadic fashion for some years. France may well wish to avoid submission of the dispute to arbitration because of a decision in her favour concerning the offshore areas appertaining to some British islands, which have a geographical position analagous to that of St. Pierre, Miquelon and Newfoundland. The policy arguments advanced by France in that case may, therefore, be used against her in such an arbitration. It may be observed that this is one dispute which might first be resolved through a system of joint exploitation and revenue-sharing with respect to petroleum operations in marine areas adjacent to the French islands. It is difficult to see how a French company could mount an economic oil and gas operation from St. Pierre and Miquelon. The use of existing Canadian of fshore support centres would be a viable alternative, even if such a solution would of fend principles of economic nationalism.

So far as the extent of the Canadian shelf is concerned, one can only say that some outstanding issues are in the process of resolution, but the one which affects Newfoundland in particular (St. Pierre and Miquelon) is likely to remain uncertain for the foreseeable future.

\section{OFFSHORE BOUNDARIES BETWEEN THE PROVINCES AND TERRITORIES}

Fixing the location of of fshore boundaries between the provinces and the territories of Canada is, like the question of of fshore mineral jurisdiction in itself, an internal matter. Such boundaries would certainly be a sine qua non of any regime which involved provincial, or territorial, offshore mineral jurisdiction. The Canada-Nova Scotia Offshore Resources Agreement is a case in point. The seaward limits of the Nova Scotia offshore area have already been discussed, as has the somewhat tentative nature of the boundary line in the Gulf of Maine, the validity of which was before the International Court of Justice at the time of writing. But the Nova Scotia of fshore area is also bounded by a line in the Bay of Fundy, and lines between Prince Edward Island, Newfoundland, and the trijunction of boundaries between Prince Edward Island, Newfoundland and Quebec. Furthermore, the eastern boundary line ignores the area claimed by France with respect to St. Pierre and Miquelon. There is, therefore, considerable uncertainty as to the location of those parts of the boundary proceeding seaward from the Bay of Fundy and in the of fshore area claimed by France. Furthermore, the Government of Newfoundland has indicated that it does not accept the boundary lines drawn by the parties to the Nova Scotia agreement which purport to determine the offshore area adjacent to that province.

If the Canada-Nova Scotia Offshore Resources Agreement is indeed the model on which further settlements will be based, it is clear that boundary lines between all Canadian ocean-coastal provinces must be 
[VOL. XXIII, NO. 1

determined. If a similar experience in the United States is any guide, the process may be far from easy, except in the case of British Columbia, where the offshore area will presumably coincide with Canada's west coast continental shelf in its entirety. If all coastal provinces are to enjoy a measure of offshore jurisdiction, then boundary lines between Manitoba and Ontario and between Ontario and Quebec will be required in Hudson Bay and James Bay.

There is a further matter to be considered here. If the government of Canada decides to extend civil and criminal law to of fshore installations using a system similar to that employed in the United States, ${ }^{53}$ then offshore boundaries will serve yet another purpose, in indicating the extent to which the law of the particular province will have extra-territorial effect. Such a system might also require the extra-territorial application of some territorial laws, and thus boundaries between the two territories, and between the Northwest Territories and Quebec and the Northwest Territories and Labrador, would also be required.

International law has built up a series of legal principles designed to resolve offshore delimitation problems. Two classic principles are those of the median line between opposite territories (e.g. the CanadaGreenland and Nova Scotia-Newfoundland of fshore boundaries) and lateral equidistance, where a line extends seawards from an onshore boundary between adjacent territories, each point of the line being equally distant from agreed points on each of the two territories (e.g. the Canadian claim in the Gulf of Maine and the New Brunswick-Nova Scotia line in the Bay of Fundy). However, the application of these principles has been complicated by a number of factors, including historical claims, inconvenient position of of fshore islands and the curvature of the coastline in certain locations. Some boundary disputes have proved intractable for years (e.g. the Gulf of Maine, St. Pierre and Miquelon), and resort to international courts or other tribunals has not always been satisfactory from the legal point of view. All that one can say here is that despite the body of legal principles available to the parties to such disputes, it is almost inevitable that the location of of fshore boundaries will be a highly politicized affair, whether the lines are imposed by the federal government, negotiated by the provinces or negotiated by the two levels of government.

\section{A SETTLED LEGAL REGIME FOR OFFSHORE PETROLEUM OPERATIONS: WHAT NOW NEEDS TO BE DONE?}

\section{A. THE REMAINING JURISDICTIONAL DISPUTES}

It will be clear from the preceding sections of this paper (and it is a somewhat depressing thought) that there remain, at least in theory, a great many jurisdictional uncertainties in Canada's of fshore. The pro-

53. Outer Continental Shelf Lands Act (1953), 67. Stat. 462 (U.S.), s.3. This section "federalizes" the law of the adjacent state and renders it applicable (except for fiscal legislation) to oil and gas facilities on the outer continental shelf, where the federal government exercises resource jurisdiction. The outer continental shelf is the area seaward of the three nautical mile (nine in the case of Florida in the Gulf of Mexico) limit; landward of that limit, the states exercise resource jurisdiction. 
vince of Nova Scotia, it should be remembered, has not abandoned its claim to exclusive jurisdiction over the Scotian Shelf (it intervened on Newfoundland's behalf in the Hibernia Reference). The joint management and revenue-sharing agreement merely states that a judicial determination in the Province's favour would not affect that accord. Nova Scotia, like the other coastal provinces, will now be waiting to observe (a) the results of other cases concerning of fshore rights, and (b) the terms of joint management and revenue-sharing agreements which may be concluded between the federal and other provincial governments.

As stated by the Supreme Court in the Hibernia Reference, nothing has yet been done to bring the appeals from the Newfoundland Reference before it. Seven years elapsed between the decision of the Court of Appeal of British Columbia in the Georgia Strait Reference and all argument on the federal appeal before the Supreme Court of Canada. If the appeals from the Newfoundland Reference are indeed pursued, it may be hoped that a less tardy timetable will be followed.

\section{B. THE RIGHT TO LEGISLATE}

The question of which level of government may exercise the "right to legislate" in respect of offshore petroleum activities generally may be answered, in part, by reference to the Constitution Act. The parties to the Newfoundland dispute were reminded of this in the course of the judgment of the Federal Court in Re Seafarers' Union and Crosbie Services. ${ }^{54}$ In that case, the Federal Court upheld the jurisdiction of the Canada Labour Relations Board in issuing certification in the of fshore, not on the grounds that the Crown in right of Canada exercised offshore petroleum jurisdiction, of which this was an incident, but because the right to legislate in matters concerning navigation and shipping was reserved to the federal Crown by the Constitution Act. ${ }^{35}$

Thus, the Federal Court appeared to be saying, "Parliament may exercise jurisdiction over entities in the of fshore which bear the character of ships". Admiralty lawyers argue, on the basis of case law (and common sense), that mobile of fshore drilling units bear the character of ships; thus, such units registered in Canada are regarded as "Canadian ships". ${ }^{56}$ In the event of recognition of provincial of fshore petroleum jurisdiction (i.e. by way of constitutional amendment), it may be argued that matters including personal safety, equipment safety and navigational safety, at least on Canadian-registered mobile of fshore drilling units, would remain the responsibility of Parliament.

The Supreme Court in the Hibernia Reference also indicated the possible limits to provincial jurisdiction vis-à-vis another outstanding issue: the applicability of Canadian civil and criminal law on of fshore installations. The Court emphasized that although provinces exercise jurisdic-

\footnotetext{
54. Supran. 34 .

55. Supran. 37, s. 91(10).

S6. W. Wylie Spicer, "Some Admiralty Issues in Offshore Oil and Gas Development", (1982) XX Alta $L$. Rev. 153, and the same author's more recent work, "Canadian Maritime Law and the Offshore: A Primer', Canadian Institute of Resources Law, (1984) Working Paper No. 6 at 8-17.
} 
[VOL. XXIII, NO. 1

tion over questions concerning property and civil rights, this jurisdiction arose only "within the province". And, according to the Court, the province exercised no jurisdiction of any kind seaward of the low-water mark. Does this limitation therefore apply to all aspects of provincial jurisdiction? If so, then creating the same legal regime for workers on offshore installations as applies to their counterparts in onshore industries, would necessitate both a considerable amount of federal legislation to match questions already addressed by the provincial Legislatures, and the provision of fora for the determination of questions arising therefrom. In the alternative, it would be open to Parliament to follow the U.S. model and "federalize" the laws of the adjacent coastal province by extending them to installations on the Canadian shelf, regardless of nationality. ${ }^{.37}$

\section{CONCLUSIONS}

The opinion of the Supreme Court of Canada in the Hibernia Reference, taken with other judicial pronouncements on continental shelf jurisdiction (the B.C. Offshore Reference, and part of the Newfoundland Reference), serves to emphasize the conditions which a province must satisfy before a claim to of fshore jurisdiction can be sustained. There must be clear evidence from the constitutional or historical record that the province had been in a position to acquire, and had acquired, extra-territorial rights of this nature. Since the Supreme Court has indicated that continental shelf rights were not available, in the absence of express claims, before 1958, it is difficult to see how a claim of this nature can be sustained in the future.

The import of the Hibernia Reference will be much discussed by constitutional and international lawyers for some time to come. Its main significance as a part of the legal regime for petroleum operations on the Grand Banks is to lay to rest one of the major areas of uncertainty. It should be stressed, however, that this uncertainty is twofold: the question before the Court was not merely one of ascertaining which level of government enjoyed wide rights over the shelf; the Court was also called upon to consider which level of government would be called upon to exercise responsibilities with respect to resources thereof. Much of the debate between the politicians was concerned with the former issue; rather less was concerned with the latter.

To some extent, the federal-provincial of fshore jurisdictional dispute acted as a drain on resources of both governments, resources which might have been put to better use. The previous section of this paper identified a number of important lacunae in Canadian law. It is suggested that several of these gaps in the legal regime are of contemporary importance far outweighing that of the jurisdictional dispute. The deficiency in Canadian law governing the conduct of operations may be revealed at any point in the conduct of an operation. Decisions as to the pace of development and production, and the allocation of revenues between governments, are only at issue when resources have been discovered in sufficient quantities and when commercial production has commenced.

57. Supran. 52. 
Neither situation is likely to develop before the end of this decade. The jurisdictional dispute could not be fairly described as premature, but it may be regarded as having been accorded an importance which it did not, perhaps, deserve.

What is clearly needed is a reorganization of political priorities with respect to offshore development. Unfortunately, recent history does not give much cause for comfort in this regard. The promulgation of legislation implementing the Canada-Nova Scotia of fshore resources agreement was an obligation accepted both by Ottawa and by Nova Scotia. For the reasons amassed above, it can hardly be regarded as an operational priority, and yet that legislation was accorded Parliamentary time in the last days of the Trudeau administration, time which might well have been devoted to more pressing matters.

The two governments concerned were not the only parties pressing for the resolution of the dispute. Members of the oil and gas industry active on the Grand Banks were equally anxious to know where they stood with respect to the permits and licences they held from both levels of government. Industry is, of course, universally known for its preference for a stable legal regime under which to operate. Nonetheless, it is suggested that both the federal and provincial governments might have pursued negotiations for a resolution of the jurisdictional dispute in a way which would not have endangered industry's level of confidence in government. Similarly, given the requisite political will, legislation to fill the legal gaps identified in the previous section could also have been passed, if necessary, by both Parliament and the Province. Premier Peckford's attitude to the constitutional settlement outlined by the Prime Minister during the 1984 election campaign appeared to reflect the satisfaction of a general who might have lost one or two battles along the way, but who finally appeared likely to win the war.

In the final analysis, Newfoundland's policy with respect to offshore jurisdiction was one where legal arguments were merely the mainstays of an argument propounded to reflect the economic and political desires of Newfoundlanders. Those desires are to control the pace of development in such a way that Newfoundland society is not shattered by the onset of sudden wealth and the orientation of the Province's industry toward the of fshore, and a determination to secure a lasting economic benefit to the Province arising out of the resources which Canada is able to enjoy only by virtue of the fact that Newfoundland chose to enter Confederation. Thus expressed, the Newfoundland argument is composed of many elements of which law is but one. The references to the Courts highlighted the legal element alone. The cogent economic and political arguments advanced by the Province were unavailing before the Courts. Several members of the Government of Newfoundland publicly expressed their displeasure with what they took to be unduely "legalistic" results in both the Newfoundland Reference and the Hibernia Reference. But it is difficult to see how the Courts could have dealt otherwise with the questions referred to them, argued as they were by counsel.

The Prime Minister's offer to implement an even-handed joint management scheme, guaranteeing one hundred percent of offshore revenues to the provinces, appears to mark the end of the jurisdictional 
dispute. However, as the survey of previous landmarks in the dispute indicated, we appear to have been at the point of settlement before. The final note on this subject can only be written once a comprehensive agreement has been negotiated and accepted by the parties concerned. In the meantime, it is to be hoped that the federal government, mindful of its legislative management responsibilities, will proceed to fill the gaps and resolve the existing ambiguities in the present legal regime for of fshore petroleum operations.

\section{ADDENDUM: THE FEBRUARY 1985 ATLANTIC ACCORD}

The Hibernia Reference effectively ended the legal debate between Ottawa and Newfoundland concerning of fshore jurisdiction. The Atlantic Accord, signed on February 11, 1985 by Prime Minister Mulroney and Premier Peckford, paved the way for a comprehensive legal and political settlement of the issue. The Province will be entitled to collect revenues from continental shelf operations as if the resources had been located on land. It has the right to fix and collect royalties, and may also collect bonuses and other rentals. The Province has an equal voice in of fshore development decisions, although the federal position will ultimately prevail if security of supply for Canada is in question.

It seems that the Province will accept a suitably modified version of the Canada Oil and Gas Act and the Oil and Gas Preservation and Conservation Act. The Canada Oil and Gas Lands Administration ("COGLA") will administer the offshore, but under the supervision of a joint federal/provincial agency which will be comprised of three appointees from each government and an independent chairman.

The Accord addresses matters considered by the Supreme Court of Canada in the second question raised in the Hibernia Reference, as set forth at the opening of Part IV, supra, namely the right to legislate in relation to the east coast of fshore. Like the Nova Scotia Agreement, the Atlantic Accord is dependent on the political will of the governments concerned. Hence, proper development and management of continental shelf activities will continue to depend upon the strength of that will and on the extent to which governments are willing to assume responsibilities for decisions which must ultimately rest with them. 